223

Received: October 26, 2016

Accepted: November 11, 2016
Macedonian Journal of Animal Science, Vol. 6, No. 2, pp. 113-118 (2016)

In print: ISSN $1857-6907$

On line: ISSN $1857-7709$

UDC: $334.722: 332.14 / .15(497.75)$

Original scientific paper

\title{
ENTREPRENEURSHIP IN THE RURAL AREAS OF THE POLOG PLANNING REGION IN THE REPUBLIC OF MACEDONIA
}

\author{
Tošo Kostadinov \\ "Ss. Cyril and Methodius" University in Skopje, Institute of Animal Science, \\ Blvd. Ilinden, 92A; P.O. box. 207, 1000 Skopje, Republic of Macedonia, \\ tosokostadinov@gmail.com
}

\begin{abstract}
The aim of this paper is to incorporate new findings in the body of knowledge regarding entrepreneurship in rural areas of the Polog Planning Region in the Republic of Macedonia. In that view interviewing was conducted with 15 owners of SMEs in rural areas who were presented four sets of statements that are important for understanding of the situation with entrepreneurship in rural areas of the Polog Planning Region in the Republic of Macedonia valued at five-degree scale from irrelevant to that of priority. One of the conclusions, by which the state of entrepreneurship of SMEs in rural areas of the Polog Region of the Republic of Macedonia is assessed, based on empirical research and compared with the results of an identical research on rural entrepreneurship on the territory of the Republic of Macedonia, is that the rural entrepreneur from that region of the country has inadequate entrepreneurial qualities, significantly lower than the entrepreneurial qualities possessed by rural entrepreneurs on the whole territory of the Republic of Macedonia. The most significant development priorities of the Polog region in the coming period are: 1) Increasing the level of economic development by raising competitiveness and productivity. 2) Improving the existing and constructing new regional transport, agriculture and communication infrastructure. 3) Improving the environment in the region and securing sustainable regional development. 4) Raising the educational level of the population and improving human resources development. 5) The Polog Planning Region is the leading agricultural region with fast rural development. 6) The Polog Planning Region is recognizable regional mountain tourism centre. 7) Improving and raising the percentage of marginalized groups in education, culture and the workforce.
\end{abstract}

Key words: Polog planning region in the Republic of Macedonia; rural entrepreneurship; rural entrepreneurs; SMEs; rural area

\section{ПРЕТРИЕМНИШТВОТО ВО РУРАЛНИТЕ ПОДРАЧЈА ВО ПОЛОШКИОТ ПЛАНСКИ РЕГИОН ВО РЕПУБЛИКА МАКЕДОНИЈА}

Целта на овој труд е да се вклучат нови наоди во корпусот на знаење за претприемништвото во руралните средини во областа на Полошкиот плански регион во Република Македонија. Во тој поглед спроведено е интервјуирање со 15 сопственици на мали и средни претпријатија (МСП)во руралните области на кои беа прикажани четири групи на искази што се важни за разбирање на ситуацијата со претприемништвото во руралните средини на Полошкиот плански регион во Република Македонија во пет-степена вредносна скала од несоодветни до онаа на приоритет. Еден од заклучоците, со што се проценува состојбата на претприемништвото во малите и средни претпријатија во руралните области на Полошкиот регион на Република Македонија - врз основа на емпириски истражувања и во споредба со резултатите од идентична истражување на руралното претприемништвото на територијата на Република Македонија - е дека руралните претприемач од овој регион на земјата имаат незадоволителни претприемнички квалитети, значително пониски од претприемничките квалитети што ги поседуваат руралните претприемачи на целата територија на Република Македонија..Најзначајни развојни приоритети на Полошкиот плански регион во наредниот период се: 1) Подигање на нивото на економски развој преку зголемување на конкурентноста и продуктивноста. 2) Подобрување на постојната и изградба на нова регионална транспортна, земјоделска и комуникациска инфраструктура. 3) Унапредување на животната средина во регионот и обезбедување на одржлив развој. 4) Подигнување на образовното ниво на населението и подобрување на развојот на човечките ресурси. 5) Полошкиот плански регион е водечки земјоделски регион со брз развој на руралните области. 6) Полошкиот плански регион е препознатлив регионален центар на планинскиот туризам. 7) Подобрување и зголемување на процентот на маргинализирана група во областа на образованието, културата и работна сила.

Клучни зборови: Полошки плански регион во Република Македонија; рурално претприемништво; рурален претприемач; МСП; рурални подрачја 


\section{INTRODUCTION}

The Polog Planning Region is located in the north-western part in the Republic of Macedonia, spread on an area of $2.416 \mathrm{sqkm}$ in the north-south direction. It includes the Polog Valley, the Mavrovo Plateau, the mountain massif Bistra and the river Radika Valley.

This planning region consists of 9 municipalities where a total population of 314.194 inhabitants live in 184 settlements. Most of the population is concentrated in the two largest municipalities: Tetovo and Gostivar, and the average population density is 126 inhabitants/sqkm, which makes it the second most densely populated region in the Republic of Macedonia after Skopje.

The region borders Albania to the west and Kosovo to the north, and there is one border crossing to Kosovo on the territory of the region, namely Jazhince.

The favourable climate conditions, as well as the relief of the Polog Planning Region offer good conditions for development of agriculture. The crops grown in the region have a unique flavor and quality, and recognizable brands both in the country and abroad are Tetovo apples, beans, paprika and patato, mountain Shar lamb, Mavrovo cheese, mountain Shar honey, etc.

The Polog Planning Region is an area rich in watercourses with large volumes of water throughout the year. Most significant rivers in the Polog Region are Vardar, Pena and Radika, with abundant fish stock, mostly trout and barbel.

The natural heritage in the region is especially rich and diverse: National Park Bistra, rivers with abundant fish stock, glacial lakes and menmade reservoirs, as well as two skiing centres (Popova Shapka and Mavrovo).

The region is also rich with cultural and historical heritage. Tetovo is one of the oldest cities in Macedonia, displaying a mixture of cultures through time. After the advance of the Ottoman Empire on the Balkans, Tetovo became an administrative centre featuring, among others, the Arabati Baba Teqe (Cemevi), the Colourful Mosque, the Citadel etc.

The Polog Planning Region has a per capita GDP of $1.531 €$, and contributes to $7.2 \%$ of the national GDP. With per capita GDP 53.1\% lower than the national average for the Republic of Macedonia, it is the least developed of the eight planning regions. Most significant industries in the re- gion are: processing, construction, agriculture, metallurgy and tourism.

\section{MATERIALS AND METHODS}

The aim of this research is based upon a base of relevant literature, documents and particularly an analysis of relevant sample of interviews (owners of 15 SMEs) to observe the conditions of the rural entrepreneurship in rural parts of the Polog Planning Region. The comparison of the obtained results with those relevant to the rural pats on the whole territory of the Republic of Macedonia (interviewed suitable sample of owners of 101 SMEs) puts mole light on the entrepreneurship in the researched region.

Several commonly used methods of economic analysis were applied in the composition of this paper, primarily the method of generalization and specialization, the method of induction and deduction, statistical method and the comparative method.

\section{RESULTS AND DISCUSSION}

Survey respondents were presented four sets of statements that are of relevance to the efforts to perceive the situation of rural entrepreneurship in the Polog Planning Region in Republic of Macedonia, valued at a five-degree scale from 1 - unimportant to 5 - priority (Table 1, 2, 3 and 4).

The results are compared to those obtained form rural areas on the territory of the Republic of Macedonia.

As major obstacles to development activities in enterprises respondents indicated high interest rates on loans, high tax rates and contributions for employees, all that in an environment of limited availability of sources of funding. However, compared to the data obtained from SMEs in rural areas of the whole territory of the Republic of Macedonia, in SMEs in rural areas of the Polog Planning Region obstacles related to the development of enterprises are significantly more emphasized.

The most important measures regarding promoting of enterprise competition on the market are development assistance programs through grants, development assistance programs through favorable loans, improving the promotion of products, and the quality of products/services. Respondents are aware of the benefit of obtaining/ having certificates of quality. 


\section{Table 1}

Degree of agreement with the statements in terms of constraints on the development of enterprises using the arithmetic means

\begin{tabular}{lcc}
\hline \hline & Mean value (rural areas) \\
& Republic of Macedonia & Polog planning region \\
\hline High rate of VAT & 3.60 & 3.84 \\
Problems with collection of claims & 3.65 & 3.76 \\
High rates of tax and employee contributions & 4.18 & 4.34 \\
Administrative difficulties and complex of procedures & 3.99 & 4.19 \\
Instability and ambiguity of the legislation & 4.02 & 4.34 \\
High interest rates on loans & 4.28 & 4.48 \\
Cost of energy & 3.92 & 4.16 \\
Cost of material, raw materials & 3.80 & 3.97 \\
Availability of funding sources & 3.99 & 4.30 \\
Loss of market in the former Yugoslavia & 3.03 & 3.16 \\
Unfair competition & 3.70 & 3.91 \\
Domestic competition & 3.86 & 3.98 \\
Obsolete technology & 3.40 & 3.53 \\
Quality of products & 3.30 & 3.55 \\
Products prices & 3.32 & 3.42 \\
Labour costs & 3.32 & 3.44 \\
Non-innovative products & 3.12 & 3.19 \\
Lack of funds for research and development & 2.84 & 2.96 \\
\hline \hline
\end{tabular}

Source: own calculations

Table 2

Degree of agreement with the statements related to improvement of the competitiveness on the market using arithmetic means.

\begin{tabular}{|c|c|c|}
\hline & \multicolumn{2}{|c|}{ Mean value(rural areas) } \\
\hline & Republic of Macedonia & Polog planning region \\
\hline Improving the quality of products and services & 4.17 & 3.96 \\
\hline Improving the promotion of products & 4.20 & 4.02 \\
\hline Obtaining quality certifications & 4.03 & 3.86 \\
\hline Professional consulting assistance & 3.46 & 3.24 \\
\hline Improvement and education in the field of entrepreneurship & 3.83 & 3.66 \\
\hline Improvement and education in the field of IT & 3.88 & 3.66 \\
\hline Improvement and education in the field of management & 3.83 & 3.69 \\
\hline Improvement and education in finance & 3.65 & 3.53 \\
\hline Improvement and education in the field of sales & 3.89 & 3.57 \\
\hline Improvement and education in marketing & 3.91 & 3.83 \\
\hline Improvement and education in foreign languages & 3.38 & 3.08 \\
\hline $\begin{array}{l}\text { Association with companies in the sector for joint appearance on } \\
\text { the market }\end{array}$ & 3.37 & 3.27 \\
\hline Assistance from development programs through grants & 4.31 & 4.14 \\
\hline Assistance from development programs through favorable loans & 4.30 & 4.16 \\
\hline Assistance from development programs through guarantee funds & 3.80 & 3.68 \\
\hline
\end{tabular}

Source: own calculations 
Table 3

Degree of agreement with claims with regard to plans for the business future (arithmetic means)

\begin{tabular}{lcc}
\hline \hline & \multicolumn{2}{c}{ Mean value (rural areas) } \\
\cline { 2 - 3 } & Republic of Macedonia & Polog planning region \\
\hline Introducing new products or services & 4.08 & 3.97 \\
Sales on a new market & 3.37 & 3.12 \\
Exploring new markets & 3.32 & 3.16 \\
Search for new distribution channels & 3.61 & 3.52 \\
Expanding advertising and promotion & 3.87 & 3.65 \\
Investing in new equipment and machinery & 3.69 & 3.57 \\
Replacement of current equipment and machinery & 3.73 & 3.58 \\
Expansion of current facilities & 3.68 & 3.55 \\
Redesign/new arrangement of the current facilities & 3.42 & 3.24 \\
Search for additional financial capital & 3.92 & 3.90 \\
Computerization of current operations & 3.29 & 3.22 \\
Upgrading of computer systems & 3.38 & 3.13 \\
Redesign of work activities & 3.29 & 3.11 \\
Expanding the scope of work activities & 3.77 & 3.60 \\
Search for professional or technical advice & 3.45 & 3.33 \\
Additional engagement of staff specialists & 3.37 & 3.22 \\
Investing in staff training (elsewhere / not in the company) & 2.63 & 2.55 \\
\hline \hline
\end{tabular}

Source: own calculations

Table 4

Degree of agreement with the statements in terms of attitudes to entrepreneurship, using the arithmetic means

\begin{tabular}{lcc}
\hline \hline & Mean value (rural areas) \\
\cline { 2 - 3 } My business is the most important activity in my life & Republic of Macedonia & Polog planning region \\
\hline I would do everything that is needed for my business to succeed & 4.13 & 4.02 \\
I plan to sell my business at the end & 4.18 & 4.10 \\
I would like to significantly contribute to the community by developing a & 2.15 & 2.35 \\
$\quad$ successful business & 4.29 & 4.16 \\
I would prefer to have my own business than to earn higher wages working for & 4.78 & 4.62 \\
$\quad$ someone else & & 3.66 \\
To run your own business is more important than have more time for the family & 3.80 & 3.72 \\
I would prefer to have my own business than to have another promising career & 4.08 & 4.13 \\
For the entrepreneur it is important to understand and accept the risk in order to & 4.26 & 3.57 \\
$\quad$ start and run a successful business & & 3.36 \\
I am ready to get into conflict with my family for the sake of running my business & 3.70 \\
I would put my house mortgaged to acquire capital for my business & 3.52 & 3.55 \\
I would be ready to have less security for my family in order to run my business & 3.67 & 3.14 \\
I run my business to continue the family tradition & 3.34 & 3.37 \\
I run my business to contribute to the welfare of my relatives & 3.52 & 3.29 \\
I run my business to live in a place that my family likes & 3.47 & 3.92 \\
I run my business to improve the status and prestige of my family & 4.02 & 4.08 \\
I run my business to have more flexibility in my personal and family life & \\
\hline \hline
\end{tabular}


Compared to the results obtained from the survey of SMEs in rural areas on the whole territory of the Republic of Macedonia, owners of SMEs from rural areas in the Polog Planning Region demonstrate significantly lower level of competitiveness.

The results of the comparative analysis have shown that owners have expressed significantly more negative attitudes regarding future plans for their businesses (Polog Planning Region) than their average counterparts from rural areas of the Republic of Macedonia.

Generally, the responses to the set of claims about the attitudes towards entrepreneurship indicate relatively affirmative attitudes towards entrepreneurship. However, responses obtained from SMEs in rural areas of the Polog planning region gives us the right to say that attitudes towards entrepreneurship among SMEs in that region are less positive than the views expressed by SMEs in rural areas on the whole territory of the Republic of Macedonia.

\section{CONCLUSION}

As major obstacles to development activities in enterprises indicated by the respondents are high interest rates on loans, high tax rates and contributions for employees, all that in an environment of limited availability of sources of funding. However, compared to the data obtained from SMEs in rural areas of the whole territory of the Republic of Macedonia, in SMEs in rural areas of the Polog Planning Region obstacles related to the development of enterprises are significantly more emphasized.

The most important measures regarding promoting of enterprise competition on the market are development assistance programs through grants, development assistance programs through favorable loans, improvement of products promotion and the quality of products/services. Respondents demonstrated to be aware of the benefits regarding obtaining/ having certificates of quality.

Compared to the results obtained from the survey of SMEs in rural areas on the whole territory of the Republic of Macedonia, owners of SMEs from rural areas in the Polog Planning Region demonstrate $\mathrm{T}$ significantly lower level of competitiveness.

The results of the comparative analysis have shown that owners have expressed significantly more negative attitudes regarding future plans for their businesses (Polog Planning Region) than their average counterparts from rural areas of the Republic of Macedonia.

Generally, the responses to the set of claims about the attitudes towards entrepreneurship indicate relatively affirmative attitudes towards entrepreneurship. However, responses obtained from SMEs in rural areas of the Polog planning region gives us the right to say that attitudes towards entrepreneurship among SMEs in that region are less positive than the views expressed by SMEs in rural areas on the whole territory of the Republic of Macedonia.

The most important development priorities for the Polog region in the coming period are:

1) Increasing the level of economic development by raising competitiveness and productivity.

2) Improving the existing and constructing new regional transport, agriculture and communication infrastructure.

3) Improving the environment in the region and securing sustainable regional development.

4) Raising the educational level of the population and improving human resources development.

5) The Polog Planning Region is the leading agricultural region with fast rural development.

6) The Polog Planning Region is recognizable regional mountain tourism centre.

7) Improving and raising the inclusion rate of marginalized group in education, culture and the workforce.

\section{REFERENCES}

[1] Janko Belak, et al. (1993): Podjetnišstvo, politika podjetja in menagement, Založba Obzorja, Maribor.

[2] P. Burns (2001): Enterprise and Small Business, Palgrave Macmillan, London.

[3] J. Burch (1986): Entrepreneurship, New York.

[4] D. W. Bygrave, A. Zacharakis: The portable MBA in Entrepreneurship, Fourth edition, John Wiley\&Son. Inc: Hoboken, New Jersey.

[5] Д. Димитров (1992): Сопствен бизнис и предприемништво. ИК Век 22, София.

[6] ИСПИ (1998): Стратегија, политика и управување со развојот на руралните средини во Република Македонија, Трибина македонска, Скопје.

[7] Коев И. (2002): Основи на претприемништво, СТЕНО, Варна.

[8] T. Kostadinov, G. Cilev, N. Nikolova (2008): Small and Medium-Sized Enterprises in the Field of Agriculture in 
the Republic of Macedonia between Competitiveness Based Strategies and the Blue Ocean Strategy, Proceedings. International Conference for Entrepreneurship Innovation and Regional Development, Skopje-Ohrid.

[9] T. Kostadinov (2011): Влијанието на претприемниитвото врз руралниот развој на Република Македонија, докторска дисертащија, Економски институт, Скопје

[10] K. W. Olm,, G. G. Eddy (1993): Entrepreneurship and Venture Management, Meril Publishing Company, USA.

[11] Ž. Pavić, (2008): Poduzetništvo mladih i nova ekonomija, Ekonomski vjesnik, No. 1-2, Zagreb.
[12] М. Пешевски (2004): Агропретприемништво, Здружение на агроекономистите на Република Македонија, Скопје,

[13] Sara Carter, Dylan Jones-Evans (2000): Enterprise and Small Business, Prentice Hall, London.

[14] N. C. Siropolis (1995): Menadžment malog poduzeća, 4 izdanje, MATE, Hrvatska Obrtnička komora, Zagreb.

[15] Т. Фити, В. Хаџи Василева-Марковска, М. Бејтмен (2007): Претприемништво, Економски факултет, Скопје

[16] Janko Belak, et aL. (1993): Podjetništvo, politika podjetja in menagement, Založba Obzorja, Maribor, 1993. 